\title{
Dampak Restocking Terhadap Nilai Produksi Ikan Di Danau Sidenreng Kabupaten Sidenreng Rappang
}

\author{
The Impact of Restocking on Fish Production Value in Lake Sidenreng, Sidenreng \\ Rappang Regency
}

\author{
Mukhlis $^{1 *}$, Abdullah B ${ }^{1}$, Henny Setiawati ${ }^{1}$ \\ Email : mukhlis.aquaculture.freshwater@gmail.com \\ ${ }^{1}$ Program Studi Agribisnis, Program Pascararjana, Universitas Muhammadiyah Parepare
}

Diterima: 10 Mei 2021 / Disetujui: 02 Agustus 2021

\begin{abstract}
ABSTRAK
Danau Sidenreng merupakan salah satu ekosistem perairan tawar yang potensial di Sulawesi Selatan, khususnya di Kabupaten Sidenreng Rappang. Pengelolaan sumberdaya perikanan Danau Sidenreng yaitu pemanfaatan sumberdaya ikan dan berkelanjutan guna meningkatkan taraf hidup/kesejahteraan masyarakat khususnya masyarakat nelayan Danau Sidenreng serta mendukung ketahanan pangan lokal. Penelitian ini bertujuan untuk mengetahui dampak apa saja yang ditimbulkan daripada kegiatan restocking terhadap nilai produksi ikan di Danau Sidenreng kabupaten Sidrap. Penelitian ini dilaksanakan di Kawasan Danau Sidenreng yang berada di tiga kecamatan yakni Kecamatan Watang Sidenreng, Kecamatan Tellu Limpoe dan Kecamatan Panca Lautang. Hasil penelitian, Kegiatan restocking berdampak terhadap nilai produksi ikan di Danau Sidenreng dan Penurunan nilai produksi ikan disebakan jenis alat tangkap yang digunakan nelayan/RTP, dimana berdasarkan hasil analisis uji T-Test perbandingan antara jenis alat tangkap dan nilai produksi ikan diperoleh output dengan dengan nilai $t$ hitung (6.794) $>\mathrm{t}$ tabel (1.65309) dan nilai Sig. $(0.000)$ < Sig.a $(0,05)$. Ini berarti H0 ditolak, sehingga dapat disimpulkan bahwa jenis alat tangkap memberikan pengaruh terhadap nilai produksi ikan di Danau Sidenreng.
\end{abstract}

Kata Kunci: Danau Sidenreng, Restocking, Nilai Produksi Ikan

\begin{abstract}
Lake Sidenreng is one of the potential freshwater ecosystems in South Sulawesi, especially in Sidenreng Rappang Regency. Management of Lake Sidenreng fishery resources, that is the use of fish resources and sustainably to improve the standard of living/welfare of the community, especially the fishing community of Lake Sidenreng and support local food security.This research was conducted in the Sidenreng Lake area, which is located in three sub-districts, that is Watang Sidenreng District, Tellu Limpoe District and Panca Lautang District. The results of the study, restocking activities have an impact on the value of fish production in Sidenreng Lake, and the decrease in fish production value is due to the type of fishing gear used by fishermen. where based on the results of the analysis of the T-Test comparison between the type of fishing gear and the value of fish production, the output is obtained with a value of t count (6.794) > t table (1.65309) and the value of Sig. (0.000) < Sig.a (0.05). This means that HO is rejected, so it can be concluded that the type of fishing gear has an influence on the value of fish production in Sidenreng Lake.
\end{abstract}

Keywords: Sidenreng Lake, Restocking, Fish Production Value.

(c) () T) This work is licensed under Creative Commons Attribution License 4.0 CC-BY International license 


\section{A. PENDAHULUAN}

Danau Sidenreng merupakan salah satu ekosistem perairan tawar yang potensial di Sulawesi Selatan, khususnya di Kabupaten Sidenreng Rappang. Hal tersebut disebabkan danau ini berfungsi sebagai penghasil ikan yang dimanfaatkan oleh masyarakat untuk memenuhi kebutuhan protein hewani, meningkatkan pendapatan nelayan, dan memperluas lapangan kerja dan kesempatan kerja bagi masyarakat di sekitar danau. Sejarah keberadaan Danau Sidenreng pada mulanya adalah satu kesatuan dari Danau Sidenreng, Danau Tempe, dan Danau Buaya disebut sistem Danau Tempe, namun ketiganya terpisah dan masingmasing mempunyai nama tersendiri yang disebabkan karena adanya sedimentasi yang berlangsung secara terus menerus dan terjadi pendangkalan. Namun saat ini pada musim hujan ketiga danau tersebut bersatu dan pada musim kemarau ketiga danau tersebut kembali terpisah (KLHRI, 2014).

Sumberdaya perikanan di danau Sidenreng, akhir-akhir ini cenderung menurun, bahkan lebih dari itu dikhawatirkan jenis ikan endemik (Glossogobius sp.) terancam punah. Banyak alasan yang dapat dikemukakan sehubungan dengan hal tersebut. Terkait dengan penangkapan ikan, sering terjadi nelayan melakukan penangkapan dengan alat yang tidak sesuai dengan standar penangkapan yang tercantum padaPeraturan Daerah (PERDA) Kabupaten Sidenreng Rappang No. 04 Tahun 2010 tentang Pengelolaan Sumberdaya Perikanan pada Perairan Umum dalam Wilayah Kabupaten Sidenreng Rappang (Lembaran Daerah Kab. Sidrap No. 04, 2010), Hal ini sangat membahayakan keberlanjutan populasi ikan. Selain itu, Leny (2005) menambahkan bahwa, selain kegiatan penangkapan yang membahayakan populasi ikan di perairan umum, kegiatan budidaya ikan di karamba/kombong tanpa perencanaan matang pada badan sungai, akan menghambat aliran air yang berdampak langsung terhadap penurunan kelarutan oksigen dalam air; serta memberi beban masukan dengan konsentrasi tinggi pada badan sungai lokasi budidaya dalam karamba/kombong dimaksud.

Kegiatan lain yang juga terlihat mempengaruhi keberlangsungan sumber daya ikan, seperti terintroduksinya ikan invasif (Hypostosmus sp.) dalam suatu perairan tersebut. Sebagaimana diketahui,bahwa ikan sapu-sapu bukan merupakan jenis ikan asli perairan tawar 
Indonesia. Jenis ini diintroduksi dari Amerika Tengah dan Amerika Selatan. Sebagaimana halnya jens-jenis mahluk hidup lain yang merupakan hasil introduksi, kadangkala memberi dampak bagi kelestarian jenis-jenis asli. Demikian pula ikan sapu-sapu, sekarang telah menjadi ancaman yang menghawatirkan tidak hanya bagi biodiversitas ikan alami, tetapi juga perekonomian masyarakat di sektor perikanan tangkap. Hal ini disebabkan ikan sapu-sapu mempunyai kemampuan adaptasi yang tinggi, dengan didukung oleh mekanisme reproduksi yang dimilikinya mampu survive dan bahkan mendominasi perairan umum (Mukhlis, dkk., 2020).

Tujuan dari pengelolaan sumber daya perikanan Danau Sidenreng yaitu pemanfaatan sumberdaya ikan dan berkelanjutan guna meningkatkan taraf hidup/kesejahteraan masyarakat khususnya masyarakat nelayan Danau Sidenreng serta mendukung ketahanan pangan lokal. Hal tersebut secara jelas dipertimbangkan dalam Peraturan Daerah Kabupaten Sidenreng Rappang No. 04 Tahun 2010 dimana upaya untuk menjaga kelestarian ekosistem perikanan pada perairan umum dalam wilayah Kabupaten Sidenreng Rappang (Lembaran Daerah Kab. Sidrap No. 04,
2010). Olehnya itu, setiap tahunnya pemerintah Kabupaten Sidenreng Rappang melalui bidang perikanan Dinas Peternakan dan Perikanan mengalokasikan anggaran kegiatan berupa penaburan benih ikan air tawar (restocking). Kegiatan restocking memiliki kepentingan khusus dalam mempertahankan keanekaragaman hayati (biodiversitas) di Danau Sidenreng. Kegiatan restocking ini juga bertujuan memperbanyak jenis ikan liar (wild stock) dengan intervensi manusia melalui upaya domestikasi dan pembudidayaan, kemudian anakannya atau stadia yang lebih besar dikembalikan ke habitat aslinya. Idealnya, upaya ini mampu mempertahankan keragaman genetik plasma nutfah (ikan-ikan asli/endemik).

Tujuan penelitian ini ada untuk mengetahui kegiatan restocking memiliki dampak terhadap peningkatan nilai produksi ikan di Danau Sidenreng dan alat tangkap berpengaruh terhadap nilai produksi ikan restocking di Danau Sidenreng.

\section{B. METODE PENELITIAN}

\section{Tempat dan Waktu Penelitian}

Penelitian ini dilaksanakan di Kawasan Danau Sidenreng yang berada di tiga kecamatan yakni Kecamatan Watang Sidenreng, Kecamatan Tellu Limpoe dan 
Kecamatan Panca Lautang. Penelitian ini dilaksanakan selama 3 bulan terhitung bulan September hingga Desember 2020.

\section{Populasi dan Sampel}

Populasi dalam penelitian ini sebanyak 408 RTP (Rumah Tangga Perikanan). RTP tersebut merupakan data yang berasal dari petugas statistik Dinas Peternakan dan Perikanan Kab. Sidrap (tidak terlaporkan dalam bentuk laporan Tahunan). Adapun jumlah sampel yang digunakan sebanyak 186 RTP. Sampel ini diperoleh dari perhitungan yang dikembangkan Isaac dan Michael dengan taraf 5\% (Sugiyono, 2015).

\section{Teknik Pengumpulan Data}

Data yang digunakan dalam kegiatan penelitian ini adalah data primer dan sekunder. Data primer yang digunakan adalah laporan produksi Nelayan Danau Sidenreng 5 tahun terakhir (2016 sampai dengan 2020. Sementara data sekunder berupa data kondisi kualitas air (Suhu, Oksigen terlarut dan $\mathrm{pH}$ ). Metode pengumpulan data primer dilakukan dengan teknik survei. Teknik survei dilakukan dengan melakukan wawancara langsung terhadap responden untuk mendapatkan informasi dan data yang dibutuhkan.

\section{Teknik Analisis Data}

Penelitian ini, kegiatan analisis data terbagi menjadi dua yakni kegiatan mendeskripsikan data dan melakukan uji statistik (inferensi). Kegiatan mendeskripsikan data adalah menggambarkan data yang ada guna memperoleh bentuk nyata dari responden, sehingga lebih mudah dimengerti peneliti atau orang lain yang tertarik dengan hasil penelitian yang dilakukan. Kegiatan mendeskripsikan data dapat dilakukan dengan pengukuran statistik deskriptif.Dalam penelitian ini, software yang digunakan adalah SPSS (Statistical Product and Service Solutions) for Windows 21 dengan analisis data sebagai berikut:

\section{a. Analisis Regresi}

Analisis regresi adalah teknik statistika yang berguna untuk memeriksa dan memodelkan hubungan diantara variabel-variabel. Regresi sering kali digunakan untuk mengatasi permasalahan, analisis regresi yang mengakibatkan suatu variabel tidak bebas (Dependent Variabel) tergantung pada variabel bebas (Independent Variabel). Model persamaan regresi yang digunakan sebagai berikut (Sugiyono, 2015):

$$
\mathbf{Y}=\mathbf{a}+\mathbf{b X}
$$

Keterangan:

$\mathrm{Y}=$ nilai produksi $(\mathrm{kg})$ 
$\mathrm{a}=$ konstanta

$\mathrm{X}=$ alat tangkap (unit)

$\mathrm{b}=$ koefisien regresi alat tangkap,

\section{b. Uji T-Test}

Uji-T atau T-Test adalah salah metode pengujian dari uji statistik parametrik. Menurut Ghozali (2012) dalam Riana dan Maria (2019), uji statistik $\mathrm{t}$ adalah suatu uji yang menunjukkan seberapa jauh pengaruh satu variabel independen secara individual dalam menerangkan variabel dependen. Pengujian statistik $t$ atau $t$-test ini dilakukan dengan menggunakan tingkat signifikansi sebesar $0,05 \quad(\alpha=5 \%)$. Penerimaan atau penolakan uji hipotesis ini dilakukan dengan kriteria sebagai berikut (Walpole, 1995 dalam Riana dan Maria, 2019):

1) Jika nilai siginifikan $>0,05$, maka hipotesis nol $\left(\mathrm{H}_{0}\right)$ diterima dan hipotesis alternatif $\left(\mathrm{H}_{1}\right)$ ditolak. Hal ini berarti, secara parsial variabel independen tersebut tidak mempunyai pengaruh yang signifikan terhadap variabel dependen.

2) Jika nilai signifikan $<0,05$ maka hipotesis nol $\left(\mathrm{H}_{0}\right)$ ditolak dan hipotesis alternatif $\left(\mathrm{H}_{1}\right)$ diterima. Hal ini berarti secara parsial variabel independen tersebut mempunyai pengaruh yang signifikan terhadap variabel dependen.

\section{HASIL DAN PEMBAHASAN}

1. Dampak Restocking

\section{a. Kondisi Restocking}

Berdasarkan data Dinas Peternakan dan Perikanan kabupaten Sidrap (2020) jumlah benih restocking Dinas peternakan dan perikanan 5 tahun terakhir (20162020) seperti terlihat pada Tabel 1.

Tabel 1. Data Restocking Benih Ikan Dinas Peternakan dan Perikanan 5 Tahun terakhir (20162020)

\begin{tabular}{ccccc}
\hline \multirow{2}{*}{ Tahun } & \multicolumn{3}{c}{ Jenis Ikan } & $\begin{array}{c}\text { Jumlah } \\
\text { Benih (ekor) }\end{array}$ \\
\cline { 2 - 4 } & Mas & Nila & Tawes & $\mathbf{6 2 5 . 0 0 0}$ \\
2016 & 312.500 & 187.500 & 125.000 & $\mathbf{2 4 0 . 0 0 0}$ \\
2017 & 120.000 & 72.000 & 48.000 & - \\
2018 & - & - & - & $\mathbf{1 9 5 . 0 0 0}$ \\
2019 & 97.500 & 58.500 & 39.000 & $\mathbf{3 7 8 . 0 0 0}$ \\
2020 & 189.000 & 113.400 & 75.600 & \\
\hline
\end{tabular}

Berdasarkan Tabel 1., Perikanan 5 tahun terakhir, setiap menggambarkan bahwa jumlah benih tahunnya tidak stabil bahkan tidak ada. restocking Dinas Peternakan dan Pada tahun 2016 jumlah benih 
restockingsebanyak 625.000 ekor meliputi ikan mas, nila dan tawes. Mulai tahun 2017 terjadi penurunan sebesar 38,4\%(240.000 ekor), tahun 2018 sebesar 100\% (0 ekor), tahun 2019 sebesar $31,20 \%$ (195.000 ekor) dan tahun 2020 mengalami peningkatan sebesar 51,58\% (378.000 ekor). Menurut Irsul (Kabid. Perikanan) berdasarkan wawancara pada tanggal 14 desember 2020, yang menyatakan bahwa"penurunan jumlah benih restocking pada tahun 2017 hingga 2019 disebabkan tidak stabilnya anggaran pemerintah, dan bahkan pada tahun 2018 tidak terealisasi disebabkan penggunaan anggaran pemerintah difokuskan pada proses pemilihan kepala daerah (pilkada)".

Adapun jenis ikan yang di restocking yaitu Ikan Nila (Oreochromis niloticus), Ikan Mas (Cyprinus carpio) dan IkanTawes (Barbonymus gonionotus). Menurut Dinas Perikanan Kabupaten Sidrap, kisaran persentase ikan Restocking ikan Nila 30\%, Ikan Mas 50\% dan Ikan Tawes sebesar $20 \%$ dari jumlah pengadaan benih Restocking tiap tahunnya.

\section{b. Kondisi Lingkungan Danau Sidenreng}

Ekosistem merupakan suatu sistem ekologi yang terdiri atas komponen yang saling berinteraksi sehingga membentuk suatu kesatuan. Genangan air yang terdapat pada danau Sidenreng bersumber dari mata air atau aliran sungai Saddang, Bila dan WalannaE (danau Tempe). Kandungan nutrien di perairan akan mempengaruhi produktivitas danau. produktivitas yang tinggi terjadi di perairan eutrofik, dimana perairan tersebut banyak menerima nutrien dari kegiatan manusia.

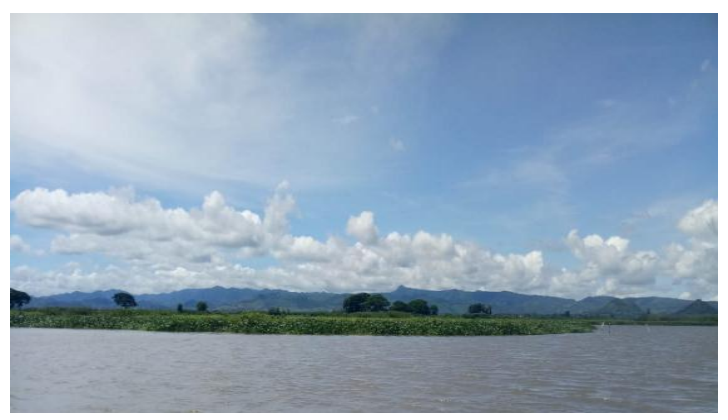

Gambar 1. Vegetasi Eceng gondok (Eichhornia crassipes) di jalur TPI

Keberadaan danau Sidenreng yang berada hilir memungkinkan adanya polusi air karena kebiasaan membuang sampah dan limbah pertanian ke badan air oleh masyarakat. Dengan pola masyarakat umum dan masyarakat pertanian yang tidak mempertimbangkan dan memperhatikan sistem pengelolaan air rumah tangga dan industri yang membuangnya langsung ke saluran drainase sampai ke sungai. Sebagaimana diketahui bahwa air merupakan sumberdaya alam terpenting dalam keberlangsungan suatu makhluk hidup akuatik terutama yang berada di danau 
Sidenreng. Air juga rentan sekali terhadap polusi yang disebabkan oleh kondisi lingkungan sekitar.

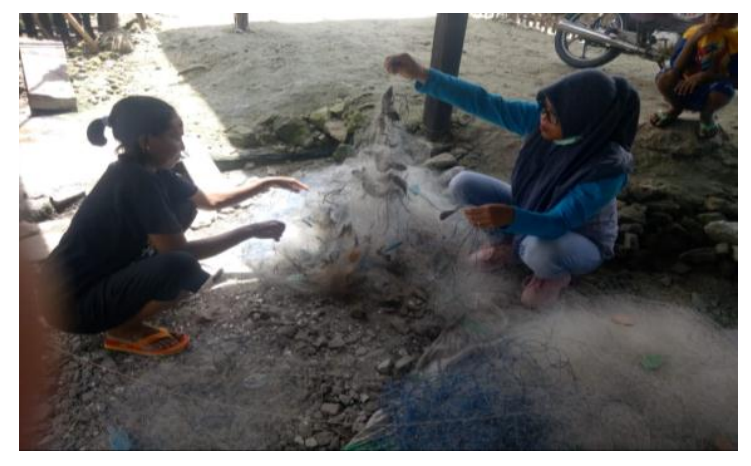

Gambar 2. Populasi Tangkap Ikan Sapusapu

Berdasarkan observasi penelitian terlihat Kondisi Danau Sidenreng yang banyak eceng gondok, membuat sebagian penduduk yang melakukan mata pencaharian seperti nelayan tangkap dan budidaya, maupun penyewaan perahu (jasa perahu) terganggu (Gambar 1).

Vegetasi dominan adalah tumbuhan yang terdapat di suatu tempat yang jumlahnya lebih banyak atau tumbuhan yang mendominasi. Dalam penelitian ini vegetasi dominan yang terdapat di danau Sidenreng adalah eceng gondok. Eceng gondok (Eichhornia crassipes) adalah salah satu jenis tumbuhan air mengapung. Eceng gondok memiliki kecepatan tumbuh yang tinggi sehingga tumbuhan ini dianggap sebagai gulma yang merusak lingkungan perairan. Adanya eceng gondok di danau Sidenreng menimbulkan dampak. Dampaknya adalah pengaruh kuat yang mendatangkan akibat (baik positif maupun negatif). Dampak yang dimaksud dalam penelitian ini adalah dampak adanya eceng gondok terhadap aktivitas ekonomi penduduk di danau Sidenreng, baik dampak positif maupun dampak negatif. Dampak positif dengan adanya eceng gondok adalah eceng gondok mempunyai sifat biologis sebagai penyaring air yang tercemar oleh berbagai bahan kimia buatan aktivitas pertanian.

Selain dampak positif dengan adanya eceng gondok di danau Sidenreng, eceng gondok juga menimbulkan dampak negatif. Dampak negatif dengan adanya eceng gondok adalah turunnya nilai estetika lingkungan yang mengurangi tingkat keindahan permukaan air, karena kita tidak dapat melihat dengan jelas dan tepat seberapa luas daerah perairan tersebut. Selain itu eceng gondok dapat menyebabkan hambatan kelancaran lalulintas air seperti mempersulit jalur transportasi air nelayan. Dampak lain yang tidak kasat mata adalah menyebabkan percepatan proses pendangkalan karena eceng gondok yang sudah mati akan turun ke dalam dasar danau hal ini juga membantu percepatan pertumbuhan bibit-bibit penyakit. Banyaknya jumlah eceng gondok di permukaan air juga menyebabkan cahaya matahari sulit masuk kedalam perairan 
dan akan menyebabkan makhluk hidup seperti ikan dapat mati karena kehabisan udara.

Disisi lain, ikan Sapu-sapu juga menjadi juga menjadi persoalan didanau Sidenreng selain eceng gondok. Berdasarkan pantauan dilapangan, ikan sapu-sapu sangat merugikan nelayan karena proses penyiangan alat tangkap semakin lama dan beresiko merusak alat tangkap nelayan. Hal ini disebabkan karena ikan sapu-sapu yang sudah tertangkap oleh tangkap nelayan akan menyebabkan kusut dan robeknya alat tangkap dalam proses penyiangan alat (Gambar 2).

Kerusakan dalam kualitas lingkungan adalah perlu dan dapat difahami untuk pertumbuhan ekonomi, dan pengelolaan sumberdaya alam agar dapat dimanfaatkan secara berkelanjutan adalah hal yang tidak dapat dilakukan oleh beberapa daerah berkembang. Akan tetapi, akhir-akhir ini semakin banyak pendapat yang muncul bahwa degradasi lingkungan dan penggunaan sumberdaya alam yang semenamena akan menimbulkan kerugian dalam jangka panjang, dan pada akhirnya akan mengurangi tujuan dari pembangunan itu sendiri yakni untuk meningkatkan kesejahteraan masyarakat secara
berkelanjutan.Kualitas air sangat berpengaruh terhadap keberhasilan restocking. Oleh karena itu perlu dilakukan pengukuran kondisi perairan yang akan ditebar apakah masih layak dalam mendukung kehidupan dan perkembangbiakan ikan tersebut.

Berdasarkan penelitian nilai kualitas air pada lokasi penelitian memiliki nilai kualitas air suhu sebesar $29,30{ }^{\circ} \mathrm{C}, \mathrm{pH}$ Air (5/asam) dan Oksigen terlarut sebesar 2,74 mg.L. Penurunan maupun peningkatan yang tidak normal pada kualitas air danau Sidenreng diduga disebabkan karena keberadaan lokasi danau yang berdada di hulu Daerah Aliran Sungai (DAS) sungai besar (Sungai Saddang) yang mana aliran sungai tersebut mengairi kegiatan pertanian dan aktivitas budidaya ikan maupun ternak lainnya. Kottelat et. al. (1993) dalam Direktorat KKJI-KKP (2015), menyatakan bahwa salah satu ancaman terhadap kelestarian ikan adalah pencemaran. Bentuk pencemaran utama di sungai dan danau adalah limbah organik yang berasal dari rumah tangga maupun industri yang menyebabkan rendahnya keasaman dan kekeruhan yang tinggi, serta perlu kandungan oksigen yang tinggi oleh bakteri untuk penghancurannya. Bila kandungan 
oksigen menurun drastis akan berakibat pada kematian ikan dan biota air lainnya.

Berdasarkan Pedoman Restocking, Direktorat KKJI-KKP (2015) menyebutkan bahwa beberapa parameter fisik-kimiawi yang bisa menyebabkan menurunnya populasi ikan apabila kisarannya sudah di luar ambang batas yang dipersyaratkan menurut baku mutu air untuk perikanan yaitu kisaran suhu air yang baik perairan antara $25-30{ }^{\circ} \mathrm{C}, \mathrm{pH}$ antara 6.5 - 8.5 dan kandungan oksigen terlarut (DO) minimal $5 \mathrm{mg} / \mathrm{l}$.

\section{c. Jenis Alat Tangkap}

Alat tangkap yang dioperasikan nelayan di danau Sidenreng yakni alat tangkap jaring insang (gill net) dan alat tangkap bubu (trap). Namun umumnya nelayan lebih cenderung menggunakan alat tangkap Jaring insang.

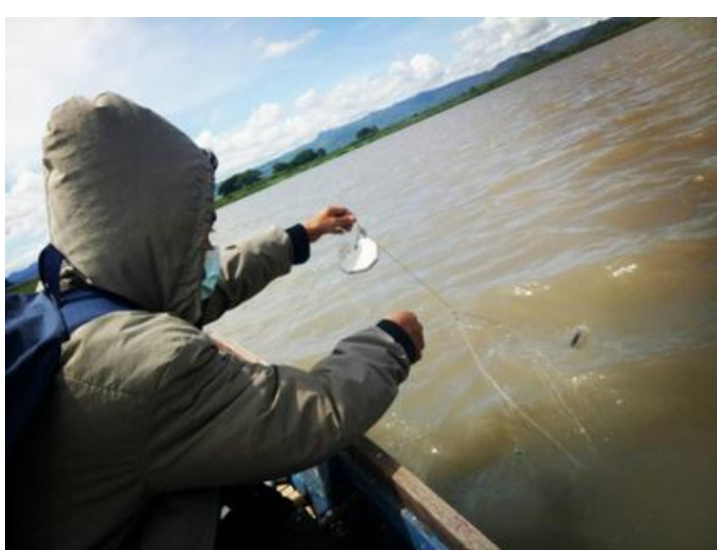

Gambar 3. Alat Tangkap Nelayan yang Beroperasi di Danau Sidenreng

Gill net atau jaring insang merupakan salah satu alat tangkap sederhana yang didesain dengan hanya menggunakan selembar anyaman (jaring) dengan tali ris sebagai bingkai tali pada jaring (Pingguo $\mathrm{He}$ and Michael Pol, 2010). Alat tangkap jaring insang merupakan alat tangkap yang digunakan dalam aktivitas penangkapan komersial.

Berdasarkan hasil penelitian (Gambar 3), terlihat penggunaan alat tangkap jaring insang/gill net (lanra) yang beroperasi di danau Sidenreng tidak sesuai dengan anjuran pemerintah yang tertuang didalam Peraturan Daerah Kabupaten Sidrap Nomor 04 Tahun 2010, dimana ukuran mata jaring insang yang digunakan oleh nelayan rata-rata berukuran $3 \mathrm{~cm}$. Dalam PERDA Nomor 04 Tahun 2010 Pasal 10 Tentang Pengelolaan Sumber Daya Perikanan Pada Perairan Umum Dalam Wilayah Kabupaten Sidenreng Rappang menyebutkan bahwa "Dalam rangka menjaga kelestarian populasi ikan, maka penggunaan alat tangkap ikan di batasi; a) Belat/kere harus berukuran tinggi maksimum 1,25 Meter dan jarak antara belahanbelahan bambu 0,5 centimeter; b) Jaring dan sejenisnya yang bahannya terbuat dari benang nilo/tasi, mata jaringnya harus berukuran sekurangkurangnya 5 Centimeter yang diukur dari jarak antara 2 simpul yang berhadapan kecuali jaring untuk udang".Hal ini 
sangat memberikan dampak negatif ukuran mata jaring insang yang terhadap keberlangsungan ikan tangkapan digunakan nelayan dalam menangkap hasil restocking karena ikan yang ikan yang berukuran kecil (diluar ditangkap oleh nelayan tidak memiliki standar). masa pertumbuhan yang optimal karena

Tabel 2. Hasil Analisis T-Tes Perbandingan Nilai Produksi Tangkap dan Jenis Alat Tangkap Utama RTP.

\begin{tabular}{|c|c|c|c|c|c|c|}
\hline & & \multicolumn{2}{|c|}{$\begin{array}{c}\text { Unstandardized } \\
\text { Coefficients }\end{array}$} & \multirow{2}{*}{$\begin{array}{c}\text { Standardized } \\
\text { Coefficients }\end{array}$} & \multirow[b]{2}{*}{$\mathrm{t}$} & \multirow[b]{2}{*}{ Sig. } \\
\hline \multicolumn{2}{|c|}{ Model } & B & Std. Error & & & \\
\hline \multirow[t]{2}{*}{1} & (Constant) & 7.309 & 1.430 & & 5.111 & .000 \\
\hline & Jenis Alat Tangkap Utama & 7.073 & 1.041 & .448 & 6.794 & .000 \\
\hline & gendent Variable: Produksi T & & & & & \\
\hline
\end{tabular}

Hasil analisis uji T-Test (Tabel 2) perbandingan antara nilai produksi tangkap dan jenis alat tangkap utama (jaring insang dan pukat) di danau Sidenreng diperoleh output dengan nilai t hitung (6.794) > t tabel (1.65309) dan nilai Sig. $(0.000)<$ Sig.a $(0,05)$. Ini berarti H0 ditolak, sehingga dapat disimpulkan bahwa jenis alat tangkap utama jaring insang dan pukat)memberikan pengaruh terhadap nilai produksi tangkap Danau Sidenreng. Menurut Laenggeng Kote (Sekretaris Dinas Peternakan dan Perikanan Sidrap) dalam wawancara pada hari Senin, 23 Nopember 2020, mengatakan bahwa "Penggunaan Lanra (jaring insang) dibawah standar aturan yang tertuang dalam PERDA Nomer 04 Tahun 2010 oleh nelayan disebabkan karena kurangnya kesadaran nelayan maupun pengawasan oleh pemerintah sendiri, mengingat Sumber Daya Manusia dalam pengawasan danau Sidenreng yang sangat terbatas". Disisi lain pemerintah kabupaten Sidrap sangat menyayangkan apa yang dilakukan nelayan mengingat dinas Peternakan dan Perikanan setiap tahunnya selalu rutin melakukan sosialisasi melalui kegiatan pemberdayaan nelayan melalui unsur penyuluh perikanan setempat.

\section{d. Nilai Produksi}

Nilai produksi adalah nilai perkiraan yang dihasilkan dari aktivitas penangkapan ikan Rumah Tangga Perikanan (RTP) Tangkap / nelayan didanau Sidenreng berdasarkan data Dinas Peternakan dan Perikanan kabupaten Sidrap 5 tahun terakhir terlihat pada Gambar 4. 


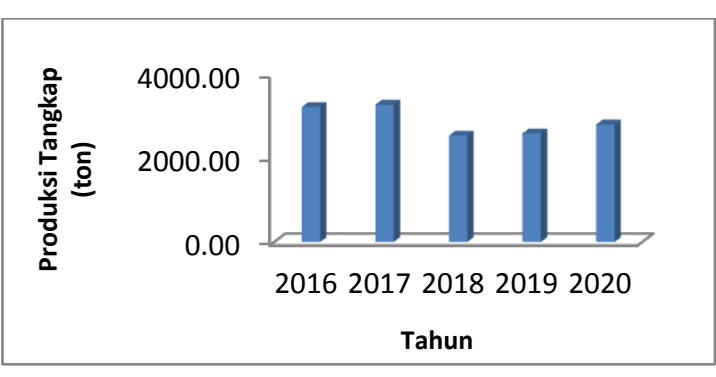

Gambar 4. Nilai Produksi RTP

Tangkap/Nelayan (Data diolah dari Dinas

Peternakan dan Perikanan, 2020)

Berdasarkan Gambar 4., jumlah produksi tangkap RTP Danau Sidenreng terlihat tidak stagnan 5 tahun terakhir. Pada tahun 2016 sebanyak 3.219,90 ton, selanjutnya tahun 2017 sebanyak 3.275,90 ton, lalu tahun 2018 sebanyak 2.536,30 ton, tahun 2019 sebanyak 2.589,70 ton dan tahun 2020 sebanyak 2.804,30 ton. Hal ini dikarenakan tidak stagnannya kegiatan dan jumlah benih restocking tiap tahunnya.

\section{Jenis Dampak Restocking}

Menurut nelayan, kegiatan restocking sangat memacu peningkatan nilai produksi tangkap danau Sidenreng terutama untuk jenis ikan Nila dan Mas yang memiliki nilai jual lebih tinggi dibandingkan dengan jenis ikan lainnya. Berdasarkan hasil penelitian, rata-rata produksi tangkap/trip nelayan (responden) terhadap spesies ikan restocking terlihat seperti pada Gambar 5.

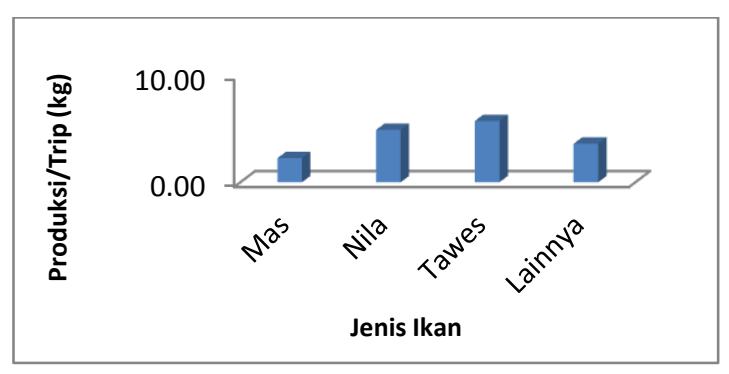

Gambar 5. Nilai Produksi Tangkap/trip (kg) RTP

Berdasarkan Gambar 5. terlihat nilai rata-rata produksi tangkap ikan restocking dan ikan lainnya (jenis ikan diluar restocking) terlihat bahwa nilai tangkap/trip nelayan danau Sidenreng tertinggi didapatkan jenis ikan Tawes $(5,73 \mathrm{~kg})$, lalu ikan Nila $(4,90 \mathrm{~kg})$, kemudian ikan Lainnya $(3,60 \mathrm{~kg})$ dan ikan Mas $(2,25 \mathrm{~kg})$. Hasil penelitian Hasrianti, dkk (2020), melaporkan bahwa persentase antara hasil tangkapan target dan tangkapan sampingan dengan hasil tangkapan buangan Sailfin catfish (Invasive species) berdasarkan jumlah (ekor) tangkapan yaitu 53,81\% untuk tangkapan spesies target \& bycatch dan 46,19\% untuk tangkapan buangan. Sebagaimana kita ketahui upaya untuk mempertahankan keberadaan jenis ikan di danau, seperti halnya yang dilakukan di danau Sidenreng. Pemerintah daerah Sidrap melakukan pengkayaan stok ikan (stock enhancement) melalui Balai Benih Ikan (BBI) lokal untuk kegiatan restocking dengan tujuan memperbanyak 
jenis ikan liar (wild stock) dengan intervensi manusia melalui pembudidayaan tanpa ada unsur domestikasi.

Disisi lain, kegiatan restocking untuk jenis benih ikan Mas dan Nila yang ditebar pemerintah daerah Sidrap bukan merupakan kegiatan restocking melaikan kegiatan stocking dan introduksi. Hal ini sesuai dengan pendapat Direktorat KKJIKKP(2015), yang mengatakan bahwa seringkali ditemukan adanya variasi pemahaman terkait restocking di kalangan praktisi perikanan, penentu kebijakan, dan masyarakat luas. Hal ini diduga tertukar dengan pemahaman kata stocking. Padahal stocking menurut FAO dalam Direktorat KKJI-KKP (2015), secara sederhana didefinisikan sebagai "the practice in raising fish in a hatchery and releasing them into a river, lake, or the ocean to supplement the existing populations or to create a population where none exist" (praktek pembesaran ikan di hatchery dan melepaskannya ke sungai, danau atau laut untuk meningkatkan populasi yang sudahada atau untuk menciptakan populasi yang sebelumnya tidak ada). Baik stocking maupun restocking dapat memiliki tujuan sama dari sisi keberlanjutan perikanan tangkap, namun restocking memiliki kepentingan khusus dalam mempertahankan keanekaragaman hayati (biodiversitas). Oleh sebab itu, restocking bekerja sepenuhnya dengan ikan liar asli (native wild stock) dari suatu habitat perairan, yang mana sebagian dari populasinya diambil untuk dipijahkan dan anakannya dikembalikan ke habitat aslinya. Idealnya, upaya ini mampu mempertahankan keragaman genetik plasma nutfah ikan-ikan asli tempatan. Upaya restocking sering ditekankan terhadap jenis asli atau endemik yang banyak mengalami tekanan kepunahan baik sebagai akibat dari tangkap lebih, degradasi habitat atau kombinasi keduanya.

Sebagaimana diketahui bahwa Danau Sidenreng merupakan satu kesatuan dari Danau Tempe yang tak terpisahkan, dan keberadaan ikan asli/endemik pada Danau Tempe merupakan bahagian ikan asli/endemik pada Danau Sidenreng. Adapun ikan asli/endemik yang ada pada Danau Tempe yaitu ikan Beloso (Glossogobius sp). Ikan Beloso (Glossogobius sp) merupakan salah satu jenis ikan asli Danau Tempe dengan nama lokal "bungo". Bernilai ekonomis tinggi dan digemari oleh masyarakat, cita rasanya istimewa dan khas dengan daging yang tebal dan tulang 
yang sedikit. Termasuk ikan liar karena belum dibudidayakan dan merupakan potensi perikanan Indonesia yang belum dikenal secara luas. Potensi ikan Beloso saat ini berada pada kondisi yang memprihatinkan. Tingginya permintaan akan ikan beloso ini, menyebabkan terjadinya penangkapan tidak terkontrol yang dilakukan oleh masyarakat. Kelompok umur populasi ikan Beloso yang ditemukan di Perairan Danau Tempe hanya terdiri atas 2 - 3 kohort (Hadijah, 2015).

\section{KESIMPULAN DAN SARAN}

Berdasarkan hasil penelitian yang telah dikemukakan, maka dapat ditarik kesimpulan bahwa kegiatan restocking berdampak terhadap nilai produksi ikan di Danau Sidenreng. Penurunan nilai produksi ikan di Danau Sidenreng disebakan jenis alat tangkap lanra (gill net) yang digunakan nelayan/RTP dibawah standar yang telah ditetapkan oleh pemerintah daerah Sidrap.

\section{DAFTAR PUSTAKA}

Akbar, J. 2017. Potensi, Peluang, dan Tantangan Pengembangan Perikanan Rawa di Kalimantan Selatan. Pusat Pengelolaan Jurnal dan Penerbitan Universitas Lambung Mangkurat. Lambung Mangkurat University Press: Banjarmasin.

Baksir, A. 1999. Hubungan antara Produktivitas Primer Fitoplankton dan Intensitas Cahaya di Waduk Cirata, Kabupaten Cianjur Jawa Barat. Tesis. Program Pascasarjana Institut Pertanian Bogor, Bogor.

BRPBATPP (Balai Riset Perikanan Budidaya Air Tawar dan Penyuluhan Perikanan. 2019. Kementerian Kelautan dan Perikanan.

https://kkp.go.id/brpbatsempur. [19 Juli 2019].

Budi, S., \& Mardiana, M. (2021). Peningkatan Pertumbuhan Dan Kecerahan Warna Ikan Mas Koi Cyprinus Carpio Dengan Pemanfaatan Tepung Wortel Dalam Pakan. Journal of Aquaculture and Environment, 3(2), 46-50.

Burhanuddin, A.I., dan Nessa, M.N., 2018. Pengantar Ilmu Kelautan dan Perikanan. Deepublish. Yogyakarta.

Direktorat KKJI-KKP. 2014. Biota Perairan Terancam Punah Indonesia Prioritas Perlindungan. Direktorat Konservasi Kawasan dan Jenis Ikan, Direktorat Jenderal Kelautan, Pesisir, dan Pulau-pulau Kecil, Kementerian Kelautan dan Perikanan.

Direktorat KKJI-KKP. 2015. Biota Perairan Terancam Punah Indonesia Prioritas Perlindungan. Direktorat Konservasi Kawasan dan Jenis Ikan, Direktorat Jenderal Kelautan, Pesisir, dan Pulau-pulau Kecil, Kementerian Kelautan dan Perikanan.

Effendi, H., 2004. Telaah Kualitas Air Bagi Pengelolaan Sumberdaya dan Lingkungan Perairan. Kanisius. Yogyakarta

Ghozali, I. (2012). Aplikasi Analisis Multivariate dengan Program IBM SPSS. Yogyakarta: Universitas Diponegoro

Hadijah, H., Mardiana, M., Indrawati, E., Budi, S., \& Zainuddin, Z. (2021). The use of artificial feed in Haliotis 
squamata farming in submerged cage culture system at Lae-Lae island, Makassar. Revista Ambiente \& Água, 16.

Hasrianti, Surianti, Rais, R (2020). Pengaruh Ledakan Populasi Ikan Sapu-Sapu ( Pterygoplichthys Spp) Terhadap Produksi Hasil Tangkapan Jaring Insang Di Perairan Danau Sidenreng.Jurnal Albacore. P-ISSN 25491326,

E-ISSN 2655559X.Volume 4, No 1, Februari 2020.

Kentasa A, 2016. Analisis Pemanfaatan Sumber Daya Alam Danau Rawa Pening Kabupaten Semarang. Skripsi. Jurusan Geografi Fakultas Ilmu Sosial: Universitas Negeri Semarang.

Kordi, M.G.H.K., 2015. Pengelolaan Perikanan Indonesia. Catatan Mengenai Potensi, Permasalahan dan Prospeknya. Pustaka Baru Press. Yogyakarta.

Lembaran Daerah Kab.Sidrap, 2010. Peraturan Daerah Kabupaten Sidenreng Rappang Tentang Pengelolaan Sumberdaya Perikanan pada Perairan Umum dalam Wilayah Kabupaten Sidenreng Rappang. Lembaran Daerah Kab.Sidrap Nomor 04 Tahun 2010: Sidrap.

Lenny S.S., 2005. Penebaran Ikan untuk Pelestarian Sumberdaya Perikanan (Fish Restocking fo Sustaining Fisheries Resources).Jurnal lktiologi Indonesia, Volume 5, Nomor 2: Bogor. http://iktiologiindonesia.org/wpcontent/uploads/2016/07/05_00052.pdf. Diakses pada tanggal 20 Juli 2020.

Mukhlis, Lausu, Makhrajani M., 2020. Pengaruh Pemberian Pakan Buatan Berupa Tepung Ikan Sapu-sapu (Hypostosmus sp) Terhadap Perumbuhan dan Sintasan Benih
Ikan Lele Dumbo (Clarias gariepinus).Prosiding Seminar Nasional Pertanian Peternakan Terpadu Ke-3, Fakultas Pertanian Universitas Muhammadiyah Purworejo 14 Maret 2020: ISBN: 978-602-60782-2-3. Universitas Muhammadiyah

Purworejo:Purworejo.

Peraturan Menteri Lingkungan Hidup. 2009. Peraturan Menteri Lingkungan Hidup Nomor 28 Tahun 2009 Tentang Daya Tampung Beban Pencemaran Air Danau dan/atau Waduk. Jakarta: Kementerian Negara Lingkungan Hidup.

Riana, M., dan Maria A.K. Analisis Penyebab dan Solusi Rekonsiliasi Finished Goods Menggunakan Hipotesis Statistik dengan Metode Pengujian Independent Sample T Test di PT.Merck, Tbk.Jurnal TEKNO (Civil Engineeering, Elektrical Engineeering and Industrial Engineeering) Vol. 16, No : 1, April 2019 , p-ISSN:19075243, e-ISSN: 2655-8416.

Soliha, S.Y., Srie, R dan Triastinurmiatiningsih. 2016. Kualitas Air Dan Keanekaragaman Plankton Di Danau Cikaret, Cibinong, Bogor.Ekologia, Vol. 16 No.2, Oktober 2016:1-10.

Sugiyono, 2015. Statistika untuk Penelitian. Cetakan ke-26. ISBN: 978-979-8433-10-8. Alfabeta: Bandung.

Suharini, Erni dan Palangan, A., 2010. Biogeografi. Semarang: Widya Karya.

Menanti, S., Indrawati, E., Mulyani, S., \& Budi, S. (2020). Analisis Efektifitas Fermentasi Limbah Perut Ikan Terhadap Pertumbuhan Dan Sintasan Ikan Lele Clarias sp. Journal of Aquaculture and Environment, 3(1), 01-05. 
Suyud, W.U., Sutriyonodan Reda, R., 2014. Ekologi. Buku materi pokok: ISBN: $\quad$ 978-979-011-325-1. Universitas Terbuka: Tangerang Selatan.

Walpole, R.E., R.H. Myers. (!995). Ilmu Peluang dan Statistika untuk Insinyur dan Ilmuwan Edisi ke-4. Bandung: Penerbit ITB

Qulubi M.H., 2019. Restocking Untuk Pelestarian Ikan Nila (Oreochromis niloticus) di Danau Kemuning Bandar Sribhawono Lampung Timur. Jurnal Soeropati ISSN: 2621-0762, Jurnal Pengabdian Kepada Masyarakat. Universitas Yudharta Pasuruan.

Yusneri, A., \& Budi, S. (2021, May). Blue swimming crab (Portunus pelagicus) megalopa stage seed feed enrichment with beta carotene. In IOP Conference Series: Earth and Environmental Science (Vol. 763, No. 1, p. 012026). IOP Publishing. 